DOI https://doi.org/10.30525/978-9934-26-180-0-22

\title{
MEANS OF VERBALIZATION OF EMOTIONS ON MORPHOLOGICAL LANGUAGE LEVEL: ENGLISH AFFIXAL MORPHEMES
}

\author{
Slipetska V. D. \\ Doctor of Philosophy, \\ Associate Professor at the Germanic Languages \\ and Translation Studies Department \\ Istitute of Foreign Languages \\ Drohobych Ivan Franko State Pedagogical University \\ Drohobych, Lviv region, Ukraine
}

Emotions and feelings of a human being, of course, are reflected in the language consciousness, conceptualized and verbalized and grammaticalized, accumulating emotional experience of a language personality, collective life of people in general, which is reproduced in the discursive practice of each language culture and a language in particular.

Russian linguist V. Shakhovsky states that emotions are a kind of human passions that permeate all spheres of a human life and are reflected at all levels of a language [5, p. 21], so not only the vocabulary system of the language, but also grammar, phonetics "imbued" with emotional overtones. Nation identification is known to occur through $\phi$ language and national intonations. Emotions are the motivational basis of human consciousness and speech behaviour [5, p. 25]. V. Shakhovsky defines emotionality as the semantic quality inherent in a language to express emotionality by the system of its means as a fact of the psyche. The scholar claims that emotionality is realized at all levels of language [5, p. 24].

Following V. Shakhovsky, O. Filimonova, a Russian researcher, defines the category of emotionality as polystatal, due to the expression of emotions at different levels of the language system - phonetic, morphological, lexical and at the level of words and sentences [4, p. 7].

"Grammar of emotions" develops issues of "emotional syntax" and "emotional morphology" (affixation, grammatical forms of words in the text) [5]. At the morphological level emotions are expressed in words whose emotional attitude to an object or phenomenon is determined by grammatical means and special affixes. It is common knowledge that a morpheme is a unit of language that contains not only the form but also its own meaning. Compared to the phoneme, this unit makes an even more significant contribution to the 
creation of content. As the main component of word formation, the morpheme interacts with the contact units of its level.

The issues of different means of verbalization of the evaluation category and means of verbalization of negative emotions are analyzed in the works of Ukrainian researchers T. Kosmeda [1], V. Slipetska [2].

The goal of the thesis is to characterize means of verbalization of emotions on a morphological language level: English affixal morphemes.

The problem of emotionality at the morphological level was analyzed in the works of O. Jesperson, I. Arnold and the others. At the morphological level, affixes can be one of the means of expressing positive or negative evaluative emotions. Analyzing the emotionality issue caused by word-formation means O. Jesperson emphasized that suffix -ish caused a negative evaluation, and hence, a negative emotion, which is facilitated by adding this suffix to the Adjective stem or the Noun stem, for example: in the Adjectives greenish [LD, c. 710] (green but not enough), greyish [LD, c. 711] (grey but not enough), yellowish (yellow but not enough) we observe some deficiency in colour; womanish [LD, c. 1898] (womanish is used to characterize men), a negative characteristics of men, hence, a negative emotion of disgust; mannish [LD, c. 1002] (mannish is used to characterize women) a negative characteristics of women, hence, a negative emotion of disgust, etc.

Diminutive suffixes function in English: -ie, -y, -ette, -ling, for example: an auntie [LD, c.84 ], a birdie [LD, c.139], an oldie [LD, c.1144], a dinette [LD, c. 437], a ducky [LD, c.486 ], a duckling [LD, c.486 ], a girly [LD, c.680], a giftling [LD, c. 679], a kitchenette [LD, c.889 ], a lordling [LD, c. 959], a nestling [LD, c. 1102 ], a roomette [LD, c.1429 ], a roomie [LD, c. 1429], a weekling [LD, c. 1871], and etc., verbalizing positive evaluation, which in turn serves as a basis for the formation of positive evaluation emotions of love, admiration, affection.

Thus, in English, at the morphological level affixal morphemes are the means of verbalization of positive and negative evaluation emotions.

\section{References:}

1. Космеда Т. А. Аксіологічні аспекти прагмалінгвістики: монографія. Львів: Львівський нац. ун-т ім. І. Франка, 2000. 349 с.

2. Сліпецька В. Д. Лінгвістика емоцій: монографія. Дрогобич: видавничий відділ ДДПУ ім. І. Франка, 2017. 347 с.

3. Филимонова О. Е. Язык и эмоции в английском языке. Когнитивный и коммуникативный аспекты: монография. СПб: Изд-во СПб гос. ун-та, 2001. 268 с. 
4. Филимонова О. Е. Автореф. дис.... д-ра филол. СПб: Изд-во СПб гос. ун-та, 2001. 44 с.

5. Шаховский В. И Категоризация эмоций в лексико-семантической системе языка: монография. Воронеж: Изд-во ВГУ, 1987. 188 с.

6. Longman Dictionary of Contemporary English. London: Longman Publishing House, 2003. 1949 p.

DOI https://doi.org/10.30525/978-9934-26-180-0-23

\title{
INTERACTION BETWEEN ADDRESSER AND ADDRESSEE IN ECOLOGICAL DISCOURSE
}

\author{
Solohub L. V. \\ Candidate of Philological Sciences, \\ Associate Professor at the Department of Foreign Languages for Sciences \\ Ivan Franko National University of Lviv \\ Lviv, Ukraine
}

The relationship between human and nature nowadays is becoming one of the most important problems which concern world's society. The study of the language in the field of environmental protection is caused by the development of people's awareness of environmental issues. In the text paradigm, text on ecology occupy an important place [2, p. 45]. Taking into consideration the definition of discourse by N. Arutyunova [1, pp. 136-137], we define ecological discourse as the set of texts on environmental issues created according to the rules of the given discourse where the key concepts are nature and environment. Ecological discourse is influenced by extralinguistic factors of ideological content (ideology and propaganda), macro-social (mass communication) and social factors (environmental problems in society). This means that ecological discourse as means of ecological thinking and behavior influences people, contributing to preserving or changing social institutions and environmental situations.

Communication in ecological discourse is provided by addresser's and addressee's interaction. From pragmatics, the written form of presenting material is the dialogue between an author and potential reader (imaginary interlocutor). The addresser acts not only as subject of cognition and transformation of reality but also as a person with the set of verbal characteristics for creating and perceiving texts. 